\title{
Front Matter: Volume 6894
}

, "Front Matter: Volume 6894," Proc. SPIE 6894, Gallium Nitride Materials and Devices III, 689401 (11 March 2008); doi: 10.1117/12.791601

SPIE Event: Integrated Optoelectronic Devices 2008, 2008, San Jose, California, United States 


\title{
PROCEEDINGS OF SPIE
}

\section{Gallium Nitride Materials and Devices III}

\author{
Hadis Morkoç \\ Cole W. Litton \\ Jen-Inn Chyi \\ Yasushi Nanishi \\ Euijoon Yoon \\ Editors
}

21-24 January 2008

San Jose, California, USA

Sponsored and Published by

SPIE 
The papers included in this volume were part of the technical conference cited on the cover and title page. Papers were selected and subject to review by the editors and conference program committee. Some conference presentations may not be available for publication. The papers published in these proceedings reflect the work and thoughts of the authors and are published herein as submitted. The publisher is not responsible for the validity of the information or for any outcomes resulting from reliance thereon.

Please use the following format to cite material from this book:

Author(s), "Title of Paper," in Gallium Nitride Materials and Devices III, edited by Hadis Morkoç,

Cole W. Litton, Jen-Inn Chyi, Yasushi Nanishi, Euijoon Yoon, Proceedings of SPIE Vol. 6894 (SPIE, Bellingham, WA, 2008) Article CID Number.

ISSN 0277-786X

ISBN 9780819470690

Published by

SPIE

P.O. Box 10, Bellingham, Washington $98227-0010$ USA

Telephone +1 3606763290 (Pacific Time) · Fax +1 3606471445

SPIE.org

Copyright (c) 2008, Society of Photo-Optical Instrumentation Engineers

Copying of material in this book for internal or personal use, or for the internal or personal use of specific clients, beyond the fair use provisions granted by the U.S. Copyright Law is authorized by SPIE subject to payment of copying fees. The Transactional Reporting Service base fee for this volume is $\$ 18.00$ per article (or portion thereof), which should be paid directly to the Copyright Clearance Center (CCC), 222 Rosewood Drive, Danvers, MA 01923. Payment may also be made electronically through CCC Online at copyright.com. Other copying for republication, resale, advertising or promotion, or any form of systematic or multiple reproduction of any material in this book is prohibited except with permission in writing from the publisher. The CCC fee code is 0277-786X/08/\$18.00.

Printed in the United States of America.

Publication of record for individual papers is online in the SPIE Digital Library.

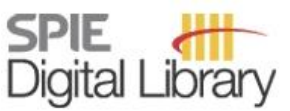

SPIEDigitalLibrary.org

Paper Numbering: Proceedings of SPIE follow an e-First publication model, with papers published first online and then in print and on CD-ROM. Papers are published as they are submitted and meet publication criteria. A unique, consistent, permanent citation identifier (CID) number is assigned to each article at the time of the first publication. Utilization of CIDs allows articles to be fully citable as soon they are published online, and connects the same identifier to all online, print, and electronic versions of the publication. SPIE uses a six-digit CID article numbering system in which:

- The first four digits correspond to the SPIE volume number.

- The last two digits indicate publication order within the volume using a Base 36 numbering system employing both numerals and letters. These two-number sets start with $00,01,02,03,04,05$, $06,07,08,09,0 \mathrm{~A}, 0 \mathrm{~B} \ldots \mathrm{OZ}$, followed by 10-1Z, 20-2Z, etc.

The CID number appears on each page of the manuscript. The complete citation is used on the first page, and an abbreviated version on subsequent pages. Numbers in the index correspond to the last two digits of the six-digit CID number. 


\title{
Contents
}

\author{
xi Conference Committee \\ xiii Introduction
}

\section{SESSION 1 GROWTH I}

689403 The role of anisotropy for defect properties in a-plane GaN [6894-02]

R. Kröger, Univ. of York (United Kingdom); T. Paskova, Kyma Technologies Inc. (USA)

689406 A thick GaN growth using GaN/Si(111) template by hydride vapor phase epitaxy (HVPE) [6894-05]

D. S. Kim, H. J. Lee, Y. J. Kim, LG Siltron (South Korea); S. K. Jong, Advanced Photonics Research Institute (South Korea); D. K. Lee, B. Y. Lee, LG Siltron (South Korea)

\section{SESSION 2 GROWTH II}

689407 Modeling and experimental analysis of RPCVD based nitride film growth [6894-06] C. Martin, K. S. A. Butcher, M. Wintrebert-Fouquet, A. Fernandes, T. Dabbs, P. P.-T. Chen, BluGlass, Ltd. (Australia); R. Carmen, Macquarie Univ. (Australia)

689408 Epitaxial lateral overgrowth of GaN on AIGaN/(111)Si micropillar array fabricated by polystyrene microsphere lithography [6894-07]

G.-T. Chen, C.-H. Chan, C.-H. Hou, H.-H. Liu, N.-W. Shiu, National Central Univ. (Taiwan); M.-N. Chang, National Nano Device Labs. (Taiwan); C.-C. Chen, J.-I. Chyi, National Central Univ. (Taiwan)

6894 OA Nanopatterning and selective area epitaxy of GaN on Si substrate [6894-09] L. S. Wang, Huazhong Univ. of Science and Technology (China) and Institute of Materials Research and Engineering (Singapore); S. J. Chua, Institute of Materials Research and Engineering (Singapore), Singapore-MIT Alliance (Singapore), and National Univ. of Singapore (Singapore); S. Tripathy, K. Y. Zang, B. Z. Wang, J. H. Teng, Institute of Materials Research and Engineering (Singapore)

\section{SESSION 3 GROWTH AND CHARACTERIZATION}

$6894 \mathrm{OB}$ Investigation of charge trapping at the oxide/semiconductor interface for MBE-grown GaN films [6894-10]

J. C. Moore, Longwood Univ. (USA); M. A. Reshchikov, J. E. Ortiz, J. Xie, H. Morkoç,

A. A. Baski, Virginia Commonwealth Univ. (USA) 
6894 OD Defect and emission distributions in bulk GaN grown in polar and nonpolar directions: a comparative analysis [6894-12]

T. Paskova, A. Hanser, E. Preble, K. Evans, Kyma Technologies, Inc. (USA); R. Kröger, Univ. of York (United Kingdom); F. Tuomisto, Helsinki Univ. of Technology (Finland); R. Kersting, Tascon GmbH (Germany); R. Alcorn, S. Ashley, C. Pagel, NSWC Crane (USA); E. Valcheva, P. P. Paskov, B. Monemar, Linköping Univ. (Sweden)

\section{SESSION 4 CHARACTERIZATION}

6894 OG Photoluminescence study of near-surface GaN/AIN superlattices [6894-15]

P. P. Paskov, B. Monemar, Linköping Univ. (Sweden); T. Paskova, Kyma Technologies Inc. (USA); S. Kamiyama, H. Amano, I. Akasaki, Meijo Univ. (Japan)

\section{SESSION 5 SPIN AND PHOTON PROPAGATION}

6894 OK Dynamics of intervalley transitions and propagation of coherent acoustic phonons in GaN single crystals studied by femtosecond pump-probe spectroscopy [6894-19]

S. WU, J. Zhang, Univ. of Rochester (USA); A. Belousov, J. Karpinski, ETH Zurich (Switzerland); R. Sobolewski, Univ. of Rochester (USA)

$6894 \mathrm{OL}$ Band coupling model of electron and hole mediated ferromagnetism in semiconductors: the case of GaN (Invited Paper) [6894-20]

S.-H. Wei, National Renewable Energy Lab. (USA); G. M. Dalpian, National Renewable Energy Lab. (USA) and Univ. Federal do ABC (Brazil)

6894 OM Spin-orbit coupling in AIGaN/AIN/GaN heterostructures with a polarization induced twodimensional electron gas (Invited Paper) [6894-21]

Ç. Kurdak, H. Cheng, Univ. of Michigan (USA); N. Biyikli, Ü. Özgür, H. Morkoç, Virginia Commonwealth Univ. (USA); V. I. Litvinov, WaveBand/Sierra Nevada Corp. (USA)

\section{SESSION 6 LASERS}

$68940 \mathrm{~N}$ Structural defects and degradation of high-power pure-blue GaN-based laser diodes (Invited Paper) [6894-22]

S. Tomiya, O. Goto, M. Ikeda, Sony Corp. (Japan)

689400 Degradation modes of high-power InGaN/GaN laser diodes on low-defect GaN substrates (Invited Paper) [6894-23]

C. C. Kim, Y. Choi, Y. H. Jang, M. K. Kang, M. Joo, M. S. Noh, LG Electronics Institute of Technology (South Korea) 
$6894 \mathrm{OQ} \quad 16 \mathrm{~nm}$ tuning range of blue InGaN laser diodes achieved by $200 \mathrm{~K}$ temperature increase [6894-25]

K. Komorowska, P. Wisniewski, Institute of High Pressure Physics Unipress (Poland);

R. Czernecki, TopGaN Ltd. (Poland); P. Prystawko, Institute of High Pressure Physics Unipress (Poland); M. Leszczynski, Institute of High Pressure Physics Unipress (Poland) and TopGaN Ltd. (Poland); T. Suski, Institute of High Pressure Physics Unipress (Poland); I. Grzegory, Institute of High Pressure Physics Unipress (Poland) and TopGaN Ltd. (Poland); S. Porowski, Institute of High Pressure Physics Unipress (Poland); S. Grzanka, TopGaN Ltd. (Poland); T. Swietlik, L. Marona, Institute of High Pressure Physics (Poland); T. Stacewicz, Warsaw Univ. (Poland); P. Perlin, Institute of High Pressure Physics Unipress (Poland) and TopGaN Ltd. (Poland)

6894 OR Why InGaN laser-diode degradation is accompanied by the improvement of its thermal stability [6894-26]

L. Marona, P. Wiśniewski, High Pressure Research Ctr. Unipress (Poland); M. Leszczyński,

I. Grzegory, High Pressure Research Ctr. Unipress (Poland) and TopGaN Ltd. (Poland);

T. Suski, S. Porowski, High Pressure Research Ctr. Unipress (Poland); R. Czernecki, TopGaN

Ltd. (Poland); A. Czerwinski, M. Pluska, J. Ratajczak, Institute of Electron Technology

(Poland); P. Perlin, High Pressure Research Ctr. Unipress (Poland) and TopGaN Ltd. (Poland)

\section{SESSION 7 DETECTORS, LIGHTING, AND LEDS}

6894 OS AIN/GaN-superlattice structures for the fabrication of intersubband detectors in the telecom wavelength range (Invited Paper) [6894-27]

D. Hofstetter, E. Baumann, F. R. Giorgetta, Univ. of Neuchatel (Switzerland); M. Maier, Fraunhofer Institute for Applied Solid State Physics (Germany); F. Guillot, E. Bellet-Amalric, E. Monroy, Equipe Mixte, CEA-CNRS-UJF Nanophysique et Semiconducteurs (France)

6894 OV Optimization of semipolar GalnN/GaN blue/green light emitting diode structures on $\{1-101\}$ GaN side facets [6894-30]

T. Wunderer, J. Hertkorn, F. Lipski, P. Brückner, M. Feneberg, M. Schirra, K. Thonke, Ulm Univ. (Germany); I. Knoke, E. Meissner, Fraunhofer IISB (Germany); A. Chuvilin, U. Kaiser, F. Scholz, Ulm Univ. (Germany)

\section{SESSION $8 \quad$ LEDS I}

6894 OW RGB LED with smart control in the backlight and lighting (Invited Paper) [6894-31]

J. C. S. Ku, C. J. Lee, Arima Optoelectronics Corp. (Taiwan)

6894 OX Highly reliable and bright GaN vertical LED on metal alloy substrate using corrugated pyramid shaped surface technology (Invited Paper) [6894-32]

J.-Y. Chu, C.-F. Chu, C.-C. Cheng, W.-H. Liu, H.-C. Cheng, F.-H. Fan, J.-K. Yen, Semi-

Photonics Co., Ltd. (Taiwan); C. A. Tran, T. Doan, SemiLEDs Corp. (USA)

SESSION 9 LEDS II

689411 High-power GaN LED chip with low thermal resistance (Invited Paper) [6894-36]

S. Hon, C. T. Kuo, T. P. Chen, M. H. Hsieh, Epistar Corp. (Taiwan) 
689412 On chip surge protection for GaN-power LEDs by ZnO thin film varistor [6894-37]

L.-B. Chang, Y.-H. Chang, Y.-S. Chang, M.-J. Jeng, Chang-Gung Univ. (Taiwan)

\section{SESSION 10 LEDs III}

689414 Recent status of white LEDs and nitride LDs (Invited Paper) [6894-39]

T. Miyoshi, T. Yanamoto, T. Kozaki, S. Nagahama, Y. Narukawa, M. Sano, T. Yamada,

T. Mukai, Nichia Corp. (Japan)

689417 True-blue InGaN laser for pico size projectors [6894-42]

U. Strau $\beta$, S. Brüninghoff, M. Schillgalies, OSRAM Opto Semiconductors GmbH (Germany);

C. Vierheilig, Univ. of Regensburg (Germany); N. Gmeinwieser, V. Kümmler,

G. Brüderl, S. Lutgen, A. Avramescu, D. Queren, D. Dini, C. Eichler, A. Lell, OSRAM Opto

Semiconductors GmbH (Germany); U. T. Schwarz, Univ. of Regensburg (Germany)

689418 Investigation of cross-sectional potential distribution in GaN-based field effect transistors by Kelvin probe force microscopy [6894-43]

M. Kaneko, A. Hinoki, A. Suzuki, T. Araki, Y. Nanishi, Ritsumeikan Univ. (Japan)

\section{SESSION 11 LEDS IV}

689419 III-nitride based deep ultraviolet light sources (Invited Paper) [6894-44]

M. S. Shur, Rensselaer Polytechnic Institute (USA) and Sensor Electronic Technology, Inc.

(USA); R. Gaska, Sensor Electronic Technology, Inc. (USA)

6894 1C AZO films with Al nano-particles to improve the light extraction efficiency of GaN-based light-emitting diodes [6894-47]

Y.-H. Chou, J.-T. Yan, H.-Y. Lee, C.-T. Lee, National Cheng Kung Univ. (Taiwan)

\section{SESSION 12 LEDs $V$}

6894 1D InGaN MQW green LEDs using $p$-In GaN and $p$-InGaN/p-GaN superlattices as $p$-type layers (Invited Paper) [6894-48]

R. D. Dupuis, J. B. Limb, J. Liu, J.-H. Ryou, C. Horne, D. Yoo, Georgia Institute of Technology (USA)

6894 IE Highly efficient InGaN/GaN LEDs with double-sided textured surfaces and omni-directional mirror structure (Invited Paper) [6894-49]

D.-S. Wuu, S.-H. Huang, R.-H. Horng, C.-Y. Hsieh, K.-W. Yen, National Chung Hsing Univ. (Taiwan)

6894 IF Development of UV-photocathodes using GaN film on Si substrate [6894-50]

S. Fuke, Shizuoka Univ. (Japan); M. Sumiya, National Institute for Materials Science (Japan); T. Nihashi, M. Hagino, M. Matsumoto, Hamamatsu Photonics K.K. (Japan); Y. Kamo,

Shizuoka Univ. (Japan); M. Sato, K. Ohtsuka, Sanken Electric Co., Ltd. (Japan)

6894 IG $\quad 1 / \mathrm{f}$ noise in nitride-based spintronic devices [6894-51]

P. H. Handel, A. M. Truong, Univ. of Missouri, St. Louis (USA) 
$6894 \mathrm{1H} \quad$ Reliability modeling of high voltage AIGaN/GaN and GaAs field-effect transistors (Invited Paper) [6894-52]

R. J. Trew, Y. Liu, W. Kuang, G. L. Bilbro, North Carolina State Univ. (USA)

$689411 \quad$ Progress in GaN device performances and reliability (Invited Paper) [6894-53]

P. Saunier, C. Lee, J. Jimenez, A. Balistreri, D. Dumka, H. Q. Tserng, M. Y. Kao, U. Chowdhury, TriQuint Semiconductor Texas (USA); P. C. Chao, K. Chu, BAE Systems (USA); A. Souzis, II-VI, Inc. (USA); I. Eliashevich, S. GUo, IQE RF (USA); J. del Alamo, J. Joh, Massachusetts Institute of Technology (USA); M. Shur, RPI (USA)

$68941 \mathrm{~J} \quad H i g h$ temperature performance measurement and analysis of GaN HEMTs [6894-54] B. A. Polash, The Univ. of Texas-Pan American (USA); M. A. Huque, S. K. Islam, Univ. of Tennessee (USA); H. Huq, The Univ. of Texas-Pan American (USA)

$6894 \mathrm{lK}$ Use of quantum 1/f noise formulas in the reliability characterization of nitride-based heterostructures [6894-55]

P. H. Handel, Univ. of Missouri, St. Louis (USA); H. Morkoç, Virginia Commonwealth Univ. (USA); A. M. Truong, Univ. of Missouri, St. Louis (USA)

\section{SESSION 14 FETS II}

$68941 \mathrm{~L}$ Millimeter-wave GaN HFET technology (Invited Paper) [6894-56]

M. Higashiwaki, National Institute of Information and Communications Technology (Japan); T. Mimura, National Institute of Information and Communications Technology (Japan) and Fujitsu Labs. Ltd. (Japan); T. Matsui, National Institute of Information and Communications Technology (Japan)

$68941 \mathrm{M}$ Status of GaN HEMT performance and reliability (Invited Paper) [6894-57]

D. S. Green, J. D. Brown, R. Vetury, S. Lee, S. R. Gibb, K. Krishnamurthy, M. J. Poulton, J. Martin, J. B. Shealy, RF Micro Devices, Inc. (USA)

6894 1N Piezoelectric quantum 1/f noise in nitride-based heterostructures (Invited Paper) [6894-58] P. H. Handel, Univ. of Missouri, St. Louis (USA); H. Morkoc, Virginia Commonwealth Univ. (USA); E. Sia, Singapore Institute of Management Univ. (Singapore); A. M. Truong, Univ. of Missouri, St. Louis (USA)

\section{SESSION $15 \quad$ FETS III}

$68941 Q \quad$ Recent progress of GaN electronic devices for wireless communication system (Invited Paper) [6894-61]

T. Kikkawa, K. Imanishi, N. Hara, H. Shigematsu, K. Joshin, Fujitsu Ltd./Fujitsu Labs. Ltd. (Japan)

6894 IR $\quad \mathrm{Al}_{\mathrm{x}} \operatorname{In}_{1-\mathrm{x}} \mathrm{N} / \mathrm{GaN}$ heterostructure field effect transistors [6894-62]

J. Xie, X. Ni, M. Wu, J. H. Leach, Ü. Özgür, H. Morkoç, Virginia Commonwealth Univ. (USA) 
6894 is GaN Schottky barrier and metal-semiconductor-metal photodetectors with in situ SiN $_{\mathbf{x}}$ nano-network [6894-63]

J. Xie, J. Mateo, Ü. Özgür, H. Morkoç, Virginia Commonwealth Univ. (USA)

6894 IT Comparative study of electroluminescence efficiency of blue (In, Ga)N and red GaAs quantum-well diodes [6894-64]

T. Inada, H. Jimi, K. Fujiwara, Kyushu Institute of Technology (Japan)

$68941 \mathrm{U}$ Infrared reflectance of optical phonon modes in AIGaN epitaxial layers grown on sapphire substrates [6894-65]

J.-R. Chen, T.-C. Lu, G.-S. Huang, T.-S. Ko, H.-C. Kuo, S.-C. Wang, National Chiao Tung Univ. (Taiwan)

6894 IV AIGaN/GaN multiple quantum wells grown by atomic layer deposition [6894-66] M. H. Lo, Z. Y. Li, J. R. Chen, T. S. Ko, T. C. Lu, H. C. Kuo, S. C. Wang, National Chiao Tung Univ. (Taiwan)

6894 IW AIGaN/SiC heterojunction bipolar transistor [6894-67]

Ya. I. Alivov, Q. Fan, X. Ni, S. Chevtchenko, Virginia Commonwealth Univ. (USA); I. B. Bhat, Rensselaer Polytechnic Institute (USA); H. Morkoç, Virginia Commonwealth Univ. (USA)

689420 Epitaxial lateral overgrowth of (1100) m-plane GaN on m-plane 6H-SiC by metalorganic chemical vapor deposition [6894-71]

X. Ni, Ü. Özgür, S. Chevtchenko, J. Nie, H. Morkoç, Virginia Commonwealth Univ. (USA);

R. P. Devaty, W. J. Choyke, Univ. of Pittsburgh (USA)

$689421 \quad$ Modification of the anomalous $V$-shaped and $S$-shaped temperature dependent photon energy in $A l_{x} G a_{1-x} N(0<x \leq 0.38)$ nanoheterostructures using a nonbonding laser lift-off (NBLLO) technique [6894-72]

A. Elgawadi, J. Krasinski, Oklahoma State Univ. (USA); G. Gainer, V. Dmitriev, Technologies and Devices International, Inc. (USA)

689424 Comparative study of deep levels in GaN grown on different templates [6894-75]

J. Nie, S. A. Chevtchenko, J. Xie, X. Ni, H. Morkoç, Virginia Commonwealth Univ. (USA)

689425 Evolution of surface morphology of polar and nonpolar GaN thin films during photoelectrochemical etching [6894-76]

J. Leach, Ü. Özgür, X. Ni, J. Xie, H. Morkoç, Virginia Commonwealth Univ. (USA)

689426 Comparison of various gate dielectrics on the performance of AIGaN/GaN HFETS [6894-77] Q. Fan, J. H. Leach, M. WU, B. Xiao, X. GU, H. Morkoç, Virginia Commonwealth Univ. (USA); P. H. Handel, Univ. of Missouri, St. Louis (USA)

689428 Optical properties of polar, nonpolar, and semipolar InGaN/GaN multiple quantum wells on sapphire [6894-79]

X. Ni, R. Shimada, J. H. Leach, J. Xie, Ü. Özgür, H. Morkoç, Virginia Commonwealth Univ. (USA) 
689429 Characterization of low-cost organic phosphor for white light-emitting diode [6894-80] F.-S. Juang, National Formosa Univ. (Taiwan); M.-H. Chang, M. O. Liu, Industrial Technology Research Institute (Taiwan); W.-R. Chen, National Formosa Univ. (Taiwan)

Author Index 
Downloaded From: https://www.spiedigitallibrary.org/conference-proceedings-of-spie on 25 Apr 2023

Terms of Use: https://www.spiedigitallibrary.org/terms-of-use 


\title{
Conference Committee
}

\author{
Symposium Chair
}

Ali Adibi, Georgia Institute of Technology (USA)

Symposium Cochair

James G. Grote, Air Force Research Laboratory (USA)

Program Track Chair

James G. Grote, Air Force Research Laboratory (USA)

Conference Chairs

Hadis Morkoç, Virginia Commonwealth University (USA)

Cole W. Litton, Air Force Research Laboratory - retired (USA)

Conference Cochairs

Jen-Inn Chyi, National Central University (Taiwan)

Yasushi Nanishi, Ritsumeikan University (Japan)

Euijoon Yoon, Seoul National University of Technology (South Korea)

Program Committee

Alison A. Baski, Virginia Commonwealth University (USA)

Tzer-Perng Chen, Epistar Corporation (Taiwan)

Shigefusa F. Chichibu, Tohoku University (Japan)

Nicolas Grandjean, École Polytechnique Fédérale de Lausanne (Switzerland)

Izabella Grzegory, Institute of High Pressure Physics Unipress (Poland) and TopGaN Ltd. (Poland)

Hideo Kawanishi, Kogakuin University (Japan)

Yong-Tae Moon, LG Electronics Inc. (South Korea)

Takashi Mukai, Nichia Corporation (Japan)

Ok-Hyun Nam, SAMSUNG Electro-Mechanics (South Korea)

Kitt Reinhardt, Air Force Office of Scientific Research (USA)

Donald J. Silversmith, Air Force Office of Scientific Research (USA)

Yan-Kuin Su, National Cheng Kung University (Taiwan)

Session Chairs

1 Growth I

Jen-Inn Chyi, National Central University (Taiwan) 
Growth II

Nicolas Grandjean, École Polyłechnique Fédérale de Lausanne (Switzerland)

3 Growth and Characterization

Euijoon Yoon, Seoul National University of Technology (South Korea)

4 Characterization

Cole W. Litton, Air Force Research Laboratory - retired (USA)

5 SPIN and Photon Propagation

Peter H. Handel, University of Missouri, St. Louis (USA)

6 Lasers

Juergen Christen, Otto-von-Guericke-Universität Magdeburg (Germany)

$7 \quad$ Detectors, Lighting, and LEDs

Johnson C. S. Ku, Arima Optoelectronics Corporation (Taiwan)

8 LEDs I

Seong-Ju Park, Gwangju Institute of Science and Technology (South Korea)

9 LEDS II

Min-Ho Kim, SAMSUNG Electro-Mechanics Co., Ltd. (South Korea)

10 LEDs III

Schang-Jing Hon, Epistar Corporation (Taiwan)

11 LEDs IV

Takashi Mukai, Nichia Corporation (Japan)

12 LEDs $\vee$

Jiunn-Yi Chu, Semi-Photonics Co., Ltd. (Taiwan)

13 FETs I

Yasushi Nanishi, Ritsumeikan University (Japan)

14 FETs II

Robert J. Trew, North Carolina State University (USA)

15 FETs III

Hadis Morkoç, Virginia Commonwealth University (USA) 


\section{Introduction}

This conference was christened as a tribute the long and productive career of Dr. G. L. Witt in 2006, and has continued very successfully in 2007 and again in 2008. As mentioned in the introduction for the 2006 GaN Materials and Devices, attainment of p-type GaN in late 1980s, and development of InGaN and lateral epitaxial overgrowth techniques broke open the logjam preventing researchers from demonstrating the many attractive attributes of GaN in devices for decades. Rapidly, even with materials nowhere near the perfection that would normally be prerequisite other materials, both optical and electronic devices with record-breaking or not previously available performance/property have been obtained.

Today, the GaN-based light emitters adorn automobiles, traffic lights, moving signs, outdoor displays, handheld electronics, and background lighting in many consumer electronics including flat panel televisions. Already, the more extensive applications of GaN light emitters in televisions and hand held devices containing displays are being felt in the marketplace. All LED outdoor white lighting applications are already in full swing with high-brightness, large-area, waferbonded LEDs producing optical power levels in excess of $200 \mathrm{~mW}$ with efficacies in excess of $100 \mathrm{l} / \mathrm{W}$ in large excitation levels. High end LEDs exhibit efficacies approaching $200 \mathrm{l} / \mathrm{W}$ and are being achieved by increasing number of LED manufacturers. Indoor general lighting applications seem to be a question of time which can be shortened with relaxation of somewhat artificially set color rendering index. For ultra high efficiency lighting systems in the $400 \mathrm{I} / \mathrm{W}$ range 4 LED approaches are being explored. It's ironic that the efficiency of heating and electric motors are higher than $70 \%$ while that of fluorescent lighting and incandescent lighting are in the range of $25 \%$ and $5 \%$, respectively. Over one third of the energy use in the US is in lighting and will approach some $1000 \mathrm{TW} / \mathrm{h}$ in the year 2020 .

With LED lighting, this increasing trend can be turned around and US consumption will actually decline if LED lighting (goes by the name solid state lighting or SSL) is adopted. Clearly incandescent and fluorescent lighting have been around for a long time and it is very unlikely that the efficacies that are available now will really see much of a discernable change in the future. In addition, fluorescent bulbs are not as reliable as touted in real use as in tests and the filaments in them degrade with repeated switching cycle not to mention the $\mathrm{Hg}$ contained in them. Against this background GaN based LEDs, particularly for general lighting applications, truly represent the hottest device today and will soon save many Terra Watts of power per year from being wasted. The four LED (namely red, yellow, green, blue) approach is considered the most efficient approach while meeting the present color rendering index guidelines (approaching 97\%) but requires source 
line widths of about $1 \mathrm{~nm}$ not to mention the stringent requirements on the wavelength of the sources used. The weak point at this point is the low efficacy for high brightness green LEDs, the so-called "green gap." As expected, efforts are underway to tackle this problem head on. Despite, and in fact because of, these challenges, these are exciting times for GaN based LEDs as they are expected to be the dominant device in the next several decades.

GaN-based lasers also are making their presence known with the introduction of Sony's PlayStation III by Sony late in 2006. With control over the content and hardware, the high-definition video systems appear to be on their way to use the BluRay technology developed by Sony which relies on GaN lasers. It is established that high-quality lasers with acceptable longevity must be grown on native substrates and or templates. This eliminated much of what could be construed as artificial problems associated with the use of lattice mismatched substrates and paved the way for tackling the real laser problems such as facet damage. It should be mentioned that in the edge emitting lasers used for these applications, one facet is coated with high reflectivity coating and does not allow light extractions. However, the emitting facet is coated with anti reflection coating for efficient photon extraction. It is this facet that undergoes damage with use. The time tested techniques such as leaving a section of the laser bar unpumped near this facet led to lifetime of over 10,000 hours at $60 \mathrm{~mW}$ power operation at room temperature. This performance is sufficient for the above mentioned applications. However, it would be unwise to assume that the push for better performance and longevity will end anytime soon.

Coming on the scene very strongly is the GaN based heterojunction FETs. Just to give a flavor, one GaN chip is now able to produce CW power levels above 700 $\mathrm{W}$ at $2 \mathrm{GHz}$ and some $10 \mathrm{~W}$ in the millimeter wave region for applications in the wireless and agile radar. It appears that the base stations for mobile communication systems will be solely the domain on GaN power amplifiers. There are, as always, problems, however, which must be dealt with. Although fine tuning of the processes as well as the device structure has continually improved power levels, cut off frequencies (both current gain and power gain cut off frequencies above $200 \mathrm{GHz}$ ), and noise figures, there are some fundamental reliability issues that are facing the community. Much of this problem is predicated on the high piezoelectric, pyroelectric, ionic nature of GaN coupled with very high drain voltages used. Even with the use of gate plates to spread the electric field some, hot electron coupling with phonons generate large densities of hot phonons which do not decay to acoustic phonons efficiently limiting carrier velocity and maintaining high lattice temperatures. Furthermore, the electrons injected into the trap levels on the surface from the gate causes the formation of a virtual gate and its extension toward the drain which is one of the causes of the drain current droop or lag. The RF stress conditions cause catastrophic degradation with TEM images in some cases showing structural damage underneath the drain side of the gate. The tensile strain present in the layers due to growth on SiC substrates in addition to the above mentioned 
problems, seem to be exacerbating the situation. The next few years will be interesting in that efforts to produce high resistivity GaN wafers for FETs are underway and when successful, the tensile strain issue mentioned previously will be out of the game.

The SPIE conference on GaN Materials and Devices was organized to disseminate the latest results and provide an opportunity for researchers from around the world to engage in discussions to advance this exciting field even further. Many world renowned invited speakers from Asia, Europe, and USA set the stage with discussions of lattice matched barriers to GaN as opposed to problematic AIGaN, the latest developments in magnetic ion doped GaN for ferromagnetism, methods to extract photons from GaN such as texturing the emission surface, flip chip mount, plasmon coupling, and photonic crystals, processes limiting internal quantum efficiency, push for higher efficacies in LEDs, particularly at the moment blue/yellow phosphor varieties, longevity in lasers and methods to increase it, high frequency and high power GaN based FETs, FET reliability, and applications of GaN to switching applications. The latter is significant as if and when successful, GaN will take away the last remaining application of $\mathrm{SiC}$ devices. This comes on top of the moves to use GaN as opposed to SiC for GaN epitaxy for FETs. Very high quality contributed papers augmented and enhanced the truly exceptional image set forth by the invited speakers. Most importantly, the meeting served the purpose of bringing experts in the field together for friendship and informal discussions of issues relevant to $\mathrm{GaN}$ and related materials and devices.

\section{Hadis Morkoç Cole W. Litton Jen-Inn Chyi Yasushi Nanishi Euijoon Yoon}


Downloaded From: https://www.spiedigitallibrary.org/conference-proceedings-of-spie on 25 Apr 2023

Terms of Use: https://www.spiedigitallibrary.org/terms-of-use 